\title{
Heritability of live weight and condition score in a Holstein herd and correlations with milk traits - preliminary estimates
}

\author{
C.J.C. Muller ${ }^{1 \#}$, S.W.P. Cloete ${ }^{1,2}$, J.J. Olivier ${ }^{3}$, J.A. Botha ${ }^{1}$ and H. de Waal ${ }^{3}$ \\ ${ }^{1}$ Institute for Animal Production: Elsenburg, Private Bag X1, Elsenburg 7607, South Africa \\ ${ }^{2}$ Department of Animal Sciences, Stellenbosch University, Private Bag X1, Matieland 7602, South Africa \\ ${ }^{3}$ ARC Livestock Business Division, Private Bag X5013, Stellenbosch 7599, South Africa
}

\begin{abstract}
Genetic and environmental parameters for live weight and condition score have been determined for Holstein cows. Genetic correlations with milk traits were also derived. Monthly records were modelled by cubic splines, while the direct, additive effects of animal and the temporary environment (defined as cow environmental effects within lactations) were fitted as random. Lactation number interacted with monthly trends in cow live weight. Cows lost weight in the early part of the lactation. This reduction in live weight was probably because of a loss in body reserves, as suggested by a lower condition score. Cows gained live weight towards the end of lactation. The ultimate live weight of cows increased with parity because of ongoing growth. The heritability $\left(\mathrm{h}^{2}\right)$ estimate for live weight was high at $0.65 \pm 0.04$, albeit still within the expected range. Condition score had a medium $\mathrm{h}^{2}$ of $0.24 \pm 0.05$. Genetic and phenotypic correlations of live weight with milk yield were positive, i.e. $0.19 \pm 0.14$ and $0.12 \pm 0.05$, respectively, while correlations of condition score with milk yield were negative, i.e. $-0.42 \pm 0.15$ and $-0.17 \pm 0.04$, respectively. Although live weight could be used as an indirect indicator of feed intake and efficiency of milk production, other body conformation traits could also be used. There is a need in the South African dairy industry for a selection index based on production parameters and some traits such as live weight, condition score or specific conformation traits. However, a large participation of animals in milk recording and measurement of such traits is a prerequisite for such developments.
\end{abstract}

Keywords: Butterfat, cows, cubic splines, environmental parameters, parity, protein

${ }^{\#}$ Corresponding author. E-mail: carelm@elsenburg.com

\section{Introduction}

Dairy farmers in South Africa are under pressure to improve the efficiency of their herds. Efficiency in any system is defined as the ratio of outputs vs. inputs (Gibson, 1984). Dairy farmers are interested in total economic efficiency rather than biological efficiency only. One definition of economic efficiency is the total income of the farm or enterprise divided by the total cost of production. Milk sales usually contribute to more than $90 \%$ of the income from dairy enterprises, while feed cost ranges from 65 to $80 \%$ of the production cost of milk (Burger, 2001). Higher efficiency can therefore only be obtained if the ratio of output (yield) relative to feed inputs can be increased. The positive genetic correlation between milk yield and feed intake (Veerkamp, 1998), as well as that between milk yield and live weight, makes it difficult to improve milk yields by selection while maintaining the live weight and feed intake of dairy cows.

While the milk yield of cows is easily measured in a dairy herd, it is difficult to determine the feed intake of cows on farm level. Generally a positive correlation exists between milk yield and efficiency of milk production (Vandehaar, 1998). Koenen et al. (2000) noted that the variation in the live weight and dry matter intake capacity of cows has considerable genetic influences, with heritability estimates of 0.45 and 0.35 , respectively. To improve the efficiency of a dairy herd it has been suggested that the breeding goal should include live weight and dry matter intake. Simulation studies suggested that Holstein-Friesian farmers in South Africa should select for cows with an increased potential for milk yield combined with a lower live weight (Du Plessis \& Roux, 1999). Other studies confirmed that selection of cows for higher milk yield resulted in heavier cows, with an increased maintenance cost (Veerkamp, 1996).

Heritability estimates for live weight are generally high, ranging from 0.24 to 0.71 (Veerkamp, 1996), particularly when weight is based on an average of more than one measurement during lactation. The correlation between milk yield and live weight depends on when cows are weighed, i.e. age or stage of 
lactation. Madgwick et al. (1991) reported a genetic correlation of 0.48 between live weight and body condition score while Veerkamp \& Brotherstone (1997) found genetic correlations ranging between 0.27 and 0.67 .

Selection of dairy cattle in New Zealand is based on an economic index known as Breeding Worth (BW). It combines a linear combination of economic weights with breeding value predictions for lactation yields of milk, fat and protein, mature cow live weights, longevity and fertility (Lopez-Villalobos \& Garrick, 2003). The live weight of lactating cows is an important measure as it reflects feeding costs related to maintenance. Although genetic parameters for yield traits have been estimated in the major South African dairy breeds, no comparable estimates are available on live weight and condition score. Relationships of milk yield with both these factors have also not been determined for Holstein cows. A selection index for dairy cattle based on these parameters is therefore not applied during selection. The major objective of this study was to obtain heritability estimates for live weight and condition score as well as their correlations with milk production traits.

\section{Materials and Methods}

This study was conducted at the Elsenburg Experimental Station of the Department of Agriculture of the Western Cape Province, using data accumulated over a 14 year period. Elsenburg is situated roughly 50 $\mathrm{km}$ east of Cape Town in the winter rainfall region of South Africa at an altitude of $177 \mathrm{~m}$, longitude $18^{\circ} 51^{\prime}$ and latitude $33^{\circ}$ 51'. The Elsenburg Holstein herd was established in 1902 and has always been used for research and training purposes. Since 1988 all lactating cows in the Elsenburg Holstein herd have been weighed and condition scored monthly, as soon as practically possible after the beginning of the month. Weights were obtained to the nearest $\mathrm{kg}$ on an electronic scale after morning milking and after the cows had been without feed and water for about two hours. At the same time they were condition scored using the Mulvany (1977) system. With this system the amount of fatty tissue under the skin is estimated at the tailhead and loin areas to give an indication of their body reserves. Body condition scores vary from 0 (very poor) to 5 (grossly fat) with half scores (adjusted for differences between the tail head and loin areas) to give an 11 point scale. Milk recording has been done in the herd since the onset of the National Milk Recording Scheme of the Animal Improvement Institute of the Agricultural Research Council in 1919. The total daily milk yield of each cow that was at least five days in milk was recorded every four weeks until 1998 and every five weeks thereafter (De Waal \& Heydenrych, 2001). Milk samples of each cow were collected at the evening and following morning's milking, composited and analysed for fat and protein concentrations with a Milko Scan Infrared Analyser in a central laboratory. This was generally done within the first two weeks of each month. Live weight and condition score records were not synchronized with milk records, as obtained from the database of the National Milk Recording Scheme. It was possible to identify live weights and condition scores that were nearest to the official milk recording dates. In total, 2671 test day records of 348 lactations of 188 cows from 1988 to 2001 were available. A total of 2435 live weight records and 2196 condition score records could be linked to these milk records obtained at the same approximate stage of lactation. In theory, lactations could be represented by a maximum of 10 test day records. The vast majority ( 2624 records, or $98 \%$ of the database) of data represented lactations with five or more test day records (i.e. cows were in milk for 150 days or longer). The average ( \pm s.d.) age of the cows at calving was $3.6 \pm 1.7$ years. The period over which data were recorded thus spanned $\sim 3.9$ generations on the female side.

All cows were fed complete diets according to National Research Council (1989) requirements. Diets consisted of oat and lucerne hay, wheat, maize, wheaten bran, cottonseed oilcake meal, fish meal, feed lime and salt. While the cows were in the milking parlour, diets were provided twice daily in fence-line feeding troughs in sufficient quantities to ensure an ad libitum intake. Feed troughs were cleaned at least twice a week to prevent residues building up. Different diets were used for primi- and multiparous cows. Primiparous cows were fed their diet separately from the rest of the herd to prevent competition at the feed trough with the bigger and older cows. They were kept on the diet for most of the lactation and were only put on pasture with a small quantity of concentrate when their body condition increased substantially. Multiparous cows were fed complete diets formulated according to the stage of the lactation (NRC, 1989). Cows in early and late lactation were fed separately in groups.

Up until 1984 very little attention was given to improve the average milk yield of cows in the Elsenburg herd. Line breeding for type to improve body conformation traits was the main emphasis during the early years of the herd. In 1984 a breeding program was started to improve the average milk yield. 
Initially first lactation cows were selected on the basis of selection threshold values based on partial lactation records (Muller \& Botha, 2003). At the same time bulls from the local semen industry were selected on the basis of predicted breeding values for $4 \%$ fat corrected milk yield and protein production. This program has been maintained until 1997, when it was changed to include body conformation traits in a mating program.

The ASREML program (Gilmour et al., 1999) is suitable for the assessment of random animal genetic and animal environmental effects in breeding experiments. The software also allows the prediction of least squares means for selected fixed effects included in the analyses to account for variation stemming from environmental causes. Fixed effects included in these analyses were year of calving (1988-2001), parity (first, second or third lactation) and season of calving (summer, autumn, winter, spring). Trends with regard to milk recording test number were modelled, using cubic splines (Gilmour et al., 1999). Smoothing splines are widely applied to longitudinal data, such as consecutive monthly test day records in this case (for a review, see Verbyla et al., 1999). Fixed linear and random non-linear components of the splines for live weight and condition score were interacted with parity and season, to obtain indications of differences between trends. Random deviations from linearity not conforming to a smooth trend were also considered initially, but were found to be not significant $(\mathrm{P}>0.05)$. In the absence of such trends for South African dairy cattle, these trends are seen as a major outcome of the study. Chronological ages of individual cows were known. Preliminary analyses involved fitting various combinations of fixed effects, random spline components and interactions between them to obtain an operational model (termed as Model 1). The result of including chronological age as a linear covariate in the analyses was that parities were adjusted to the same mean, while general trends for test-days prevailed. The same basic result was obtained when chronological age was fitted within parity number. In view of the importance of parity specific trends throughout lactation, the regression on chronological age was excluded from further analyses. Other effects found to be significant $(\mathrm{P}<0.05)$ in these preliminary analyses were retained in subsequent analyses. Random terms were then added to the operational model, resulting in the following single-trait genetic models for analyses (in matrix notation):

$$
\begin{aligned}
& \mathrm{y}=X \mathrm{X}+\mathrm{Z}_{1} \mathrm{c}_{\mathrm{PE}}+\mathrm{e} \\
& \mathrm{y}=\mathrm{Xb}+\mathrm{Z}_{1} \mathrm{a}+\mathrm{e} \\
& \mathrm{y}=\mathrm{Xb}+\mathrm{Z}_{1} \mathrm{a}+\mathrm{Z}_{2} \mathrm{c}_{\mathrm{PE}}+\mathrm{e} \\
& \mathrm{y}=\mathrm{Xb}+\mathrm{Z}_{1} \mathrm{c}_{\mathrm{TE}}+\mathrm{e} \\
& \mathrm{y}=\mathrm{Xb}+\mathrm{Z}_{1} \mathrm{a}+\mathrm{Z}_{3} \mathrm{c}_{\mathrm{TE}}+\mathrm{e} \\
& \mathrm{y}=\mathrm{Xb}+\mathrm{Z}_{1} \mathrm{c}_{\mathrm{PE}}+\mathrm{Z}_{3} \mathrm{c}_{\mathrm{TE}}+\mathrm{e} \\
& \mathrm{y}=\mathrm{Xb}+\mathrm{Z}_{1} \mathrm{a}+\mathrm{Z}_{2} \mathrm{c}_{\mathrm{PE}}+\mathrm{Z}_{3} \mathrm{c}_{\mathrm{TE}}+\mathrm{e}
\end{aligned}
$$

In these models, $y$ was a vector of observations for cow live weight, condition score or milk traits; $b$, $\mathrm{a}, \mathrm{c}_{\mathrm{PE}}$ and $\mathrm{c}_{\mathrm{TE}}$ were vectors of fixed effects, direct genetic effects, cow permanent environmental effects and cow temporary environmental effects, respectively; $X, Z_{1}, Z_{2}$, and $Z_{3}$ were the corresponding incidence matrices relating the respective effects to $y$, and e the vector of residuals. Temporary environmental variances were defined as cow environmental effects within lactations, while permanent environmental effects denoted the correspondence between records on the same animal across lactations.

It was assumed that:

$$
\mathrm{V}(\mathrm{a})=\mathrm{A} \sigma_{\mathrm{a}}^{2} ; \mathrm{V}\left(\mathrm{c}_{\mathrm{PE}}\right)=\mathrm{I} \sigma_{\mathrm{PE}}^{2} ; \mathrm{V}\left(\mathrm{c}_{\mathrm{TE}}\right)=\mathrm{I} \sigma_{\mathrm{TE}}^{2} ; \mathrm{V}(\mathrm{e})=\mathrm{I} \sigma_{\mathrm{e}}^{2} \text {, }
$$

with $A$ the numerator relationship matrix, I being an identity matrix; and $\sigma_{\mathrm{a}}^{2}, \sigma_{\mathrm{PE}}^{2}, \sigma_{\mathrm{TE}}^{2}$ and $\sigma_{\mathrm{e}}^{2}$ being the direct genetic variance, cow permanent environmental variance, cow temporary environmental variance and environmental (residual) variance respectively. All analyses included the full pedigree file, consisting of 263 individuals, the progeny of 98 sires and 196 dams.

It is conceded that an unstructured repeatability model as used in the present study is not the best approach for an analysis of this nature, as means and variances for the same trait at different ages may differ. However, in view of the relatively small data set, as well as the low number of cows included, it is regarded as a suitable approach for this preliminary study.

Likelihood ratio tests (LRT) were conducted to determine the most suitable model for each trait in uni-variate analyses. The LRT was based on testing twice the increase in the Log likelihood resulting from adding random terms to the model of analysis as a $\mathrm{Chi}^{2}$ statistic. Alternatively, for two models with the same number of random effects, and assuming identical fixed effects models, the one with the higher likelihood fits the data better. Subsequently, two-trait animal models were fitted. These analyses allowed the 
calculation of direct and cow permanent or temporary environmental correlations between traits, together with their appropriate standard errors.

\section{Results and Discussion}

The coefficients of variation for live weight and the percentage traits were in the 11-16\% range (Table 1). Condition score and yield traits were highly variable, as reflected by coefficients of variation exceeding $25 \%$. This variation in daily milk yield is, however, expected as milk recordings were from all stages of the lactation and across one to three parities. Haile-Mariam et al. (2003) also found coefficients of variation of between 24 and $30 \%$ for milk yield, $8 \%$ for protein percentage and 15 to $18 \%$ for fat percentage for HolsteinFriesian cows in Australia at their first to seventh milk recording tests. Coefficients of variation derived from data supplied by Mostert et al. (2003) from the national Holstein herd were 28.3, 29.5 and 28.1\% for milk, fat and protein yield, respectively. Live weight and condition score are the most important traits in this study. Results on milk traits are provided solely to demonstrate that it coincided with results from much larger and more informative data sets in the National Milk Recording Scheme.

Table 1 Means, standard deviations, coefficient of variation (CV) and ranges for live weight, condition score and milk traits of cows in a Holstein herd from first to third lactation

\begin{tabular}{lcccc}
\hline \multicolumn{1}{c}{ Trait } & $\begin{array}{c}\text { Number of } \\
\text { observations }\end{array}$ & Mean \pm s.d. & $\begin{array}{c}\text { CV } \\
(\%)\end{array}$ & Range \\
\hline Live weight (kg) & 2435 & $533 \pm 71$ & 13.3 & $332-783$ \\
Condition score (n) & 2196 & $2.64 \pm 0.83$ & 31.4 & $1-5$ \\
Milk yield (kg/day) & 2671 & $23.9 \pm 7.3$ & 30.5 & $2.0-56.4$ \\
Fat yield (kg/day) & 2655 & $0.848 \pm 0.256$ & 30.2 & $0.09-2.26$ \\
Protein yield (kg/day) & 2655 & $0.780 \pm 0.223$ & 28.6 & $0.09-1.76$ \\
Fat (\%) & 2655 & $3.60 \pm 0.59$ & 16.4 & $0.54-6.71$ \\
Protein (\%) & 2655 & $3.30 \pm 0.38$ & 11.5 & $2.29-5.17$ \\
& & & & \\
\hline
\end{tabular}

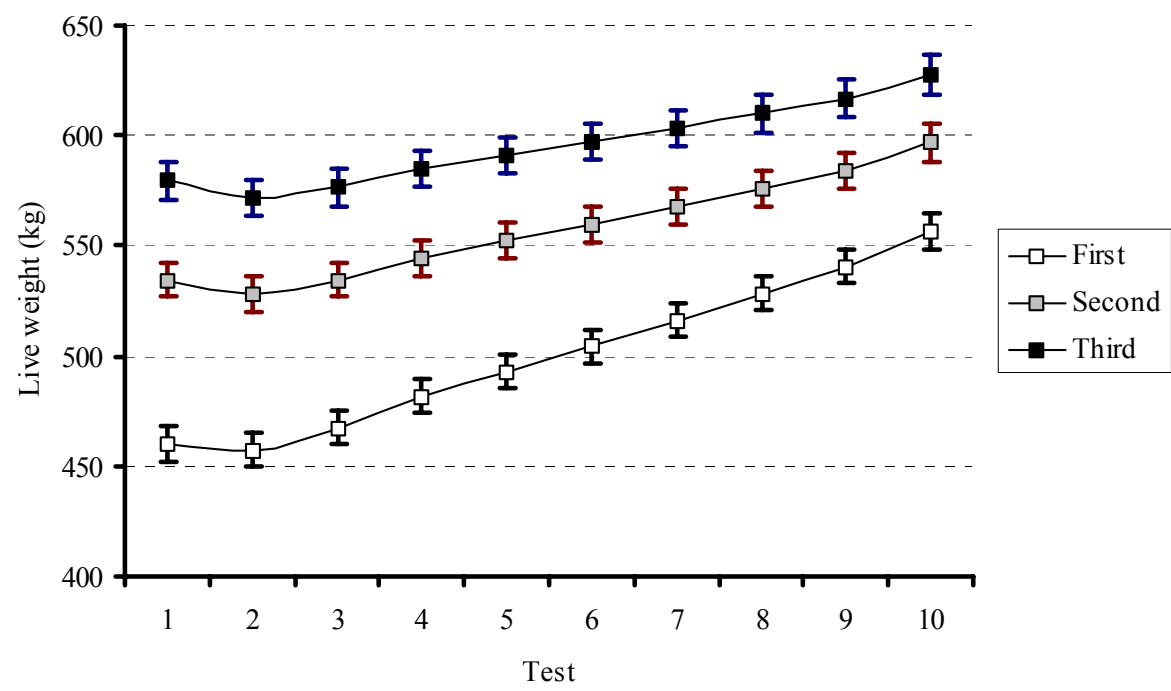

Figure 1 The interaction between parity and test number for first, second and third lactation cows for live weight. Vertical bars about the means depict standard errors

In terms of the fixed effects, it was evident that lactation number interacted with the linear component of the spline for test number in the case of cow live weight (Figure 1). Cows lost weight in the early part of 
the lactation, while live weight increased towards the end of lactation. The incline in live weight of primiparous cows was steeper than for multiparous cows $(\mathrm{P}<0.05)$. This trend is probably related to primiparous cows still growing during the lactation period, as their live weights at the start of the lactation were generally lower than recommended live weight targets (Heinrichs \& Hargrove, 1987). The ultimate live weight of cows increased with parity (Figure 2). This is primarily due to cows growing to reach a mature live weight at third calving (Fox et al., 1999). The lactation curves obtained in this study are not provided, because they were similar to those obtained by Mostert et al. $(2001$; 2003) for South African Holstein cows and Haile-Mariam et al. (2003) for Australian Holstein-Friesian cows. However, it was evident that trends in live weight mirrored the traditional lactation curves reported by Mostert et al. (2001; 2003).

Condition score declined somewhat at the beginning of lactation (Figure 2), before increasing markedly as lactation progressed. The response curves for cows in the different parities were all similar in shape, and no significant differences were observed $(P>0.05)$. Season of calving interacted with the linear and nonlinear components of the splines for test number for live weight and condition score. Cows calving in summer gained condition at a faster rate than their contemporaries calving in other seasons (Figure 3).

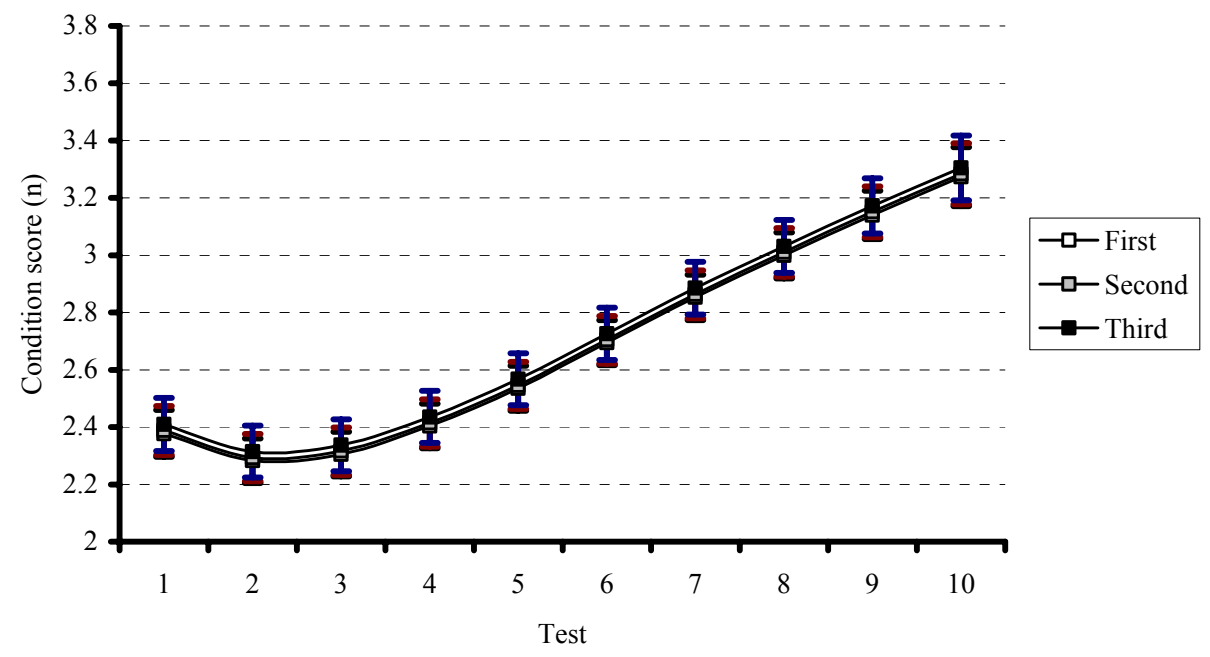

Figure 2 The interaction between parity and test number for first, second and third lactation cows for condition score. Vertical bars about the means depict standard errors

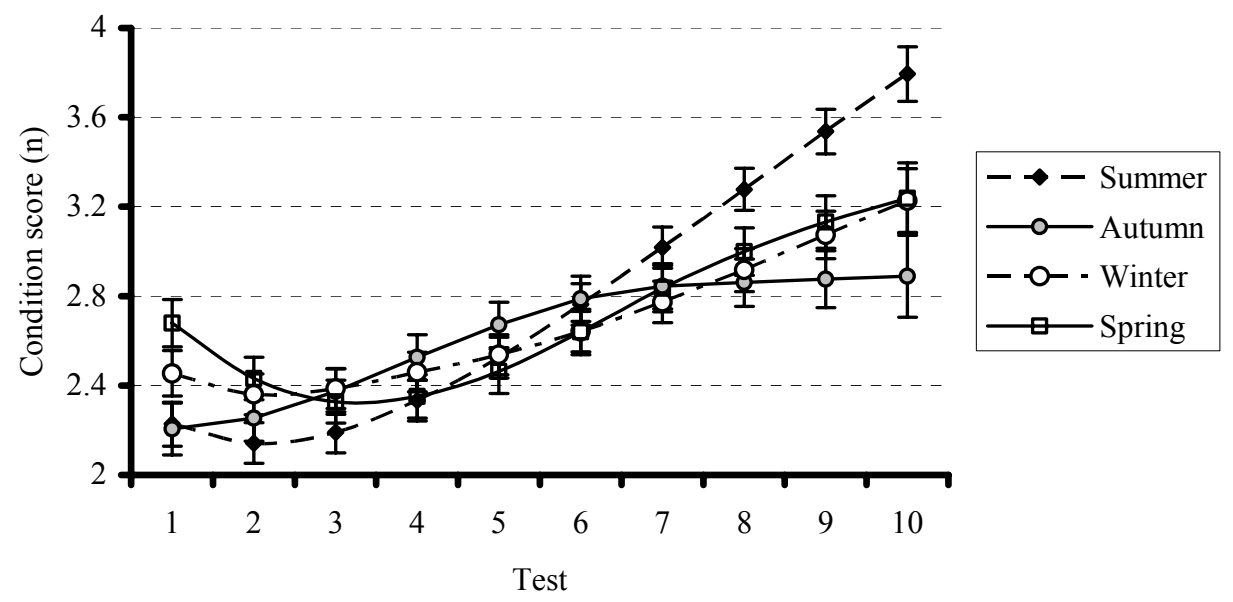

Figure 3 The interaction between season of calving and test number for cows calving in the summer, autumn, winter and spring. Vertical bars about the means depict standard errors 
Trends for condition score of cows calving in winter and spring were similar in shape. These cows, however, started at a better $(\mathrm{P}<0.05)$ condition and showed a slower gain in condition as lactation progressed. Cows calving in autumn did not gain condition from test number 6 towards the end of lactation. The reason for this is not clear, but could be related to increasing environmental temperatures towards the end of the lactation resulting in an adverse effect on feed intake.

The LRT revealed that Model 6, including direct additive and cow temporary environmental effects fitted the data best for all traits except for condition score (Table 2). Model 7, including cow permanent and temporary environmental effects, fitted the data marginally better than Model 6 for the latter trait. However, for consistency in reporting the outcomes of results from the study, it was decided to also fit Model 6 to the condition score data for the purpose of the study. The $\mathrm{h}^{2}$ estimate for live weight was particularly high at 0.65 , but still within the expected range. Condition score had a medium heritability. Estimates of $\mathrm{h}^{2}$ were in the medium range for the yield traits and butterfat percentage (Table 3). Protein percentage was highly heritable. Heritability estimates for milk fat, protein, milk volume and live weight for New Zealand dairy cows were $0.28,0.31,0.35$ and 0.30, respectively (Livestock Improvement Corporation, 1996). Veerkamp (1998) showed in a review that $\mathrm{h}^{2}$ estimates for milk yield varied between 0.16 to 0.50 while estimates for live weight varied between 0.24 and 0.71 . These estimates were from various studies of cows and heifers under different feeding programmes, and are subject to large sampling errors. Heritability estimates for live weight were generally high, especially when weight was based on an average of more than one measurement. Spelman \& Garrick (1997) found $h^{2}$ estimates of $0.22,0.25,0.28$ and 0.24 for milk fat, milk protein, milk volume and live weight respectively in New Zealand dairy cows. Kadarmideen \& Wegmann (2003) found $\mathrm{h}^{2}$ estimates of $0.23,0.26,0.21,0.27,0.57,0.47$ for body condition score, milk yield, fat yield, protein yield, fat percentage and protein percentage respectively for Holstein cows in Switzerland.

Table 2 Log likelihood ratios for the respective traits under different models of analysis $\left(\sigma^{2}{ }_{A}-\right.$ direct additive variance, $\sigma_{\mathrm{PE}}^{2}-$ cow permanent environmental variance, $\sigma_{\mathrm{TE}}^{2}-$ cow temporary environmental variance). The best models are denoted in bold figures

\begin{tabular}{cccccccc}
\hline \multirow{2}{*}{ Model } & \multirow{2}{*}{ Live weight } & Condition & \multicolumn{3}{c}{ Yields } & \multicolumn{2}{c}{ Percentages } \\
\cline { 5 - 7 } & & score & Milk & Butterfat & Protein & Butterfat & Protein \\
\hline & & & & & & & \\
2 & -10674.50 & -486.44 & -5638.68 & 2887.17 & 3290.43 & 195.87 & 1849.22 \\
3 & -9561.75 & -232.92 & -5193.92 & 3211.54 & 3684.53 & 414.68 & 2222.35 \\
4 & -9550.46 & -236.19 & -5193.12 & 3210.20 & 3687.96 & 415.20 & 2233.38 \\
5 & -9548.88 & -230.50 & -5189.90 & 3215.07 & 3691.57 & 417.54 & 2233.41 \\
6 & -9401.95 & -190.63 & -5017.30 & 3299.75 & 3793.74 & 399.30 & 2171.19 \\
7 & $-\mathbf{9 3 3 6 . 2 7}$ & -173.11 & $\mathbf{- 5 0 0 2 . 5 8}$ & $\mathbf{3 3 1 5 . 8 6}$ & $\mathbf{3 8 1 6 . 5 4}$ & $\mathbf{4 2 7 . 3 8}$ & $\mathbf{2 2 3 9 . 9 5}$ \\
8 & -9348.23 & $\mathbf{- 1 7 2 . 8 7}$ & -5004.50 & 3313.99 & 3810.73 & 425.81 & 2229.22 \\
& -9335.83 & -171.01 & -5001.76 & 3316.95 & 3817.16 & 428.46 & 2239.95 \\
\hline
\end{tabular}

$$
\begin{aligned}
& \text { Model } 1-\text { Fixed only } \\
& \text { Model } 2 \text { - Fixed }+\sigma_{\mathrm{PE}}^{2} \\
& \text { Model } 3 \text { - Fixed }+\sigma_{\mathrm{A}}^{2} \\
& \text { Model } 4 \text { - Fixed }+\sigma_{\mathrm{A}}^{2}+\sigma_{\mathrm{PE}}^{2} ; \\
& \text { Model } 5 \text { - Fixed }+\sigma_{\mathrm{TE}}^{2} \\
& \text { Model } 6 \text { - Fixed }+\sigma_{\mathrm{A}}^{2}+\sigma^{2} \mathrm{TE} \\
& \text { Model } 7 \text { - Fixed }+\sigma_{\mathrm{PE}}^{2}+\sigma_{\mathrm{TE}}^{2} \\
& \text { Model } 8 \text { - Fixed }+\sigma_{\mathrm{A}}^{2}+\sigma_{\mathrm{PE}}^{2}+\sigma_{\mathrm{TE}}^{2}
\end{aligned}
$$

The cow temporary environment accounted for respectively 0.16 and 0.18 of the phenotypic variation for live weight and condition score. Corresponding estimates for yield traits ranged between 0.23 and 0.30 , while cow temporary environment accounted for less than $10 \%$ of the phenotypic variation for the percentage traits. 
Table 3 Variance components and ratios for milk and body traits in Holstein cows from first to third lactation $\left(\sigma_{\mathrm{A}}^{2}-\right.$ direct additive variance, $\sigma^{2} \mathrm{TE}-$ cow temporary environmental variance, $\sigma_{\mathrm{E}}^{2}-$ environmental variance, $\sigma_{\mathrm{P}}^{2}-$ phenotypic variance)

\begin{tabular}{crrccccc}
\hline Variances and & Live & Condition & \multicolumn{3}{c}{ Yield traits } & \multicolumn{2}{c}{ Percentages } \\
\cline { 6 - 8 } ratios & weight & score & Milk & Butterfat & Protein & Butterfat & Protein \\
\hline Variances: & & & & & & & \\
$\sigma^{2} \mathrm{~A}$ & 1907.0 & 0.1342 & 7.649 & 0.0098 & 0.0078 & 0.0860 & 0.0325 \\
$\sigma^{2} \mathrm{TE}$ & 484.0 & 0.1032 & 8.328 & 0.0097 & 0.0073 & 0.0220 & 0.0035 \\
$\sigma_{\mathrm{E}}^{2}$ & 557.0 & 0.3246 & 11.716 & 0.0218 & 0.0146 & 0.2074 & 0.0532 \\
$\sigma_{\mathrm{P}}^{2}$ & 2984.0 & 0.5620 & 27.693 & 0.0413 & 0.0297 & 0.3154 & 0.0892 \\
& & & & & & & \\
Ratios: & & & & & & & \\
$\mathrm{h}^{2}$ & $0.65 \pm 0.04$ & $0.24 \pm 0.05$ & $0.28 \pm 0.06$ & $0.24 \pm 0.05$ & $0.26 \pm 0.05$ & $0.27 \pm 0.04$ & $0.36 \pm 0.04$ \\
$\mathrm{t}^{2}$ & $0.16 \pm 0.03$ & $0.18 \pm 0.03$ & $0.30 \pm 0.04$ & $0.23 \pm 0.04$ & $0.24 \pm 0.04$ & $0.07 \pm 0.02$ & $0.04 \pm 0.01$ \\
\hline
\end{tabular}

$\mathrm{h}^{2}$ - heritability

$\mathrm{t}^{2}$ - cow temporary environment

Although all yield traits were positively related to cow weight, only the genetic correlation for protein and butterfat yield reached statistical significance (more than double the corresponding standard error). The genetic correlations of the percentage traits with live weight were positive as well, but the cow temporary environmental correlations and the environmental correlations were variable (Table 4). Genetic, cow temporary environmental, phenotypic and environmental correlations among the yield traits were high to very high, while butterfat and protein percentages were negatively related to milk yield. These results were consistent with literature values, and are not provided in detail.

Table 4 Genetic, temporary environmental, phenotypic and environmental correlations of live weight and condition score with milk traits in Holstein cows using data from the first three lactations

\begin{tabular}{lcccc}
\hline & \multicolumn{4}{c}{ Correlations } \\
\cline { 2 - 5 } Traits & Genetic & $\begin{array}{c}\text { Temporary } \\
\text { environmental }\end{array}$ & Phenotypic & Environmental \\
\hline Live weight X: & $0.52 \pm 0.09$ & $0.83 \pm 0.05$ & $0.46 \pm 0.04$ & $0.30 \pm 0.02$ \\
Condition score & $0.19 \pm 0.14$ & $0.07 \pm 0.10$ & $0.12 \pm 0.05$ & $0.10 \pm 0.02$ \\
Milk yield & $0.35 \pm 0.13$ & $0.07 \pm 0.10$ & $0.18 \pm 0.05$ & $0.09 \pm 0.02$ \\
Butterfat yield & $0.29 \pm 0.13$ & $0.07 \pm 0.10$ & $0.17 \pm 0.05$ & $0.12 \pm 0.02$ \\
Protein yield & $0.30 \pm 0.11$ & $-0.00 \pm 0.14$ & $0.14 \pm 0.04$ & $0.05 \pm 0.02$ \\
Butterfat \% & $0.29 \pm 0.10$ & $-0.08 \pm 0.16$ & $0.17 \pm 0.05$ & $0.12 \pm 0.02$ \\
Protein \% & & & & $-0.07 \pm 0.02$ \\
& & & & $-0.04 \pm 0.02$ \\
Condition score X: & $-0.42 \pm 0.15$ & $-0.12 \pm 0.11$ & $-0.17 \pm 0.04$ & $-0.09 \pm 0.02$ \\
Milk yield & $-0.50 \pm 0.14$ & $-0.07 \pm 0.11$ & $-0.16 \pm 0.04$ & $0.05 \pm 0.02$ \\
Butterfat yield & $-0.43 \pm 0.14$ & $-0.05 \pm 0.11$ & $-0.17 \pm 0.04$ & $0.01 \pm 0.02$ \\
Protein yield & $0.04 \pm 0.15$ & $-0.08 \pm 0.14$ & $0.03 \pm 0.04$ & $0.06 \pm 0.04$ \\
Butterfat \% & $0.15 \pm 0.12$ & $0.04 \pm 0.18$ & & \\
Protein \% & & & & \\
\end{tabular}

Veerkamp (1998) also found variable genetic correlations between live weight and milk yield, the correlation depending on when live weight was measured. Van Elzakker \& Van Arendonk (1993) found that the genetic correlation between yield and live weight differed between 0.29 in week 3 of the lactation to -0.25 in week 13 of the lactation. It was suggested that the most likely reason for the difference in genetic correlations is the fact that body reserves are being used in the early part of the lactation when cows are in a 
negative energy balance (Veerkamp, 1998). This reasoning is supported by the present study where yield traits were generally negatively related to condition score, the genetic correlations being in the $0.4-0.5$ range. Correlations between percentage traits and condition score were low and variable. Spelman \& Garrick (1997) found genetic correlations of $0.34,0.37$ and 0.39 between live weight and fat, protein and milk volumes, respectively. Kadarmideen \& Wegmann (2003) also found moderate positive genetic correlations between body condition score and milk yield, fat and protein percentage, i.e. 0.17, 0.19, 0.17, respectively, while the genetic correlation between body condition score and fat and protein yield was moderately negative ( -0.27 and -0.19 , respectively).

All correlations between live weight and condition score were positive in sign and particularly high on the genetic and cow temporary environmental levels. Madgwick et al. (1991) accordingly found a genetic correlation of 0.48 between live weight and condition score. Similarly, Veerkamp \& Brotherstone (1997) found genetic correlations between live weight and condition score ranging from 0.27 to 0.67. Body condition score therefore explains a significant part of the genetic variation in live weight (Veerkamp, 1998), suggesting that adjustments should be made when comparing the actual live weight of dairy cows.

Veerkamp \& Brotherstone (1997) found that adjustment of live weight for condition score changed a slightly negative genetic correlation of -0.09 between milk yield and live weight to a moderately positive correlation of 0.29 between milk yield and adjusted live weight. These authors have suggested that the association between yield and live weight is more dynamic than other parameters such as size (e.g. stature, chest width and body depth) because both yield and live weight are closely associated with the mobilization of body reserves. Recent studies by Coffey et al. (2001) have shown that body condition score could be used in selecting profitable animals because of its strong genetic relationship with other functional traits such as body weight and feed efficiency.

Various studies have indicated that selection for milk yield has a strong negative effect on live weight change during lactation. Veerkamp (1998) found genetic correlations between yield and live weight change that ranged from -0.37 to -0.84 . This could indicate that high genetic merit cows could mobilize more body reserves to ensure maximum milk production, while also growing less during lactation. Body condition score could be used to indicate energy balance (Veerkamp, 1998). The heritability estimate for body condition score in the present study was similar to that of milk yield, i.e. 0.24 vs. 0.28. Madgwick et al. (1991) found a correlation of -0.05 between milk yield and body condition score while Veerkamp \& Brotherstone (1997) found a value of -0.46 in a high yielding herd of Holsteins with condition score measured throughout lactation. They found that the genetic correlation between body condition score and milk yield was only -0.18 for primiparous cows, indicating that the lower body condition score (and live weight) for cows of high genetic merit is because of a greater mobilization of body tissue during the lactation.

Although live weight could be included in a selection index for dairy cattle, Koenen (2002) has noted that the implementation of a large-scale genetic evaluation for body weight based on regular weighing of cows is an unrealistic option for practical reasons. Veerkamp (1998) also noted that the measurement of the performance of an individual cow for live weight and feed intake is not a common practice in most breeding schemes. It has been suggested that other body conformation traits such as chest circumference or height could be used as indirect indicators of live weight and feed intake. Veerkamp \& Brotherstone (1997) found that genetic correlations between live weight and stature, chest width, body depth, and rump height were high, while chest width and body depth were lowly to moderately correlated with dry matter intake. As dairy cows are scored for linear type traits by representatives of breed societies according to standard procedures for registration purposes, some of these traits could be used as an indirect measure of live weight and dry matter intake of cows. A selection index based on production parameters and some conformation traits could therefore be constructed for each dairy breed.

\section{Conclusions}

This study reports $\mathrm{h}^{2}$ estimates for live weight and condition score in a South African dairy herd, as well as genetic correlations of these traits with milk traits. Values are comparable to estimates reported in the literature. These parameters need to be verified in a more representative sample of the local Holstein breed. Options set out in the discussion concerning body conformation traits should also be considered. It will only then be possible to apply the results to the local dairy industry as a whole. A selection index based on production parameters and some conformation traits could therefore be constructed for the Holstein breed. Further studies are therefore considered necessary. 


\section{Acknowledgements}

The authors thank H.E. Theron and her team for providing test-day milk records of Holstein cows from the national database of the Animal Improvement Institute, Irene. The help of S.A. Holstein in providing pedigree information of the Elsenburg Holstein cows is also gratefully acknowledged.

\section{References}

Burger, W.P., 2001. Ekonomiese aspekte van melkbeesboerderye. Melkbeesvoedingskursusnotas. Dept van Landbou : Wes-Kaap. Elsenburg. 7607

Coffey, M.P., Emmans, G.C. \& Brotherstone, S., 2001. Genetic evaluation of dairy bulls for energy balance traits using random regression. Anim. Sci. 73, 29-40.

De Waal, H. \& Heydenrych, H.J., 2001. The effect of sampling frequency on the accuracy of estimates of milk-fat yields of dairy cows. S. Afr. J. Anim. Sci. 31, 9-11.

Du Plessis, M. \& Roux, C.Z., 1999. A breeding goal for South African Holstein Friesians in terms of economic weights in percentage units. S. Afr. J. Anim. Sci. 29, 237-244.

Fox, D.G., Van Amburgh, M.E. \& Tylutki, T.P., 1999. Predicting requirements for growth, maturity, and body reserves in dairy cattle. J. Dairy Sci. 82, 1968-1977.

Gibson, J.P., 1984. Efficiency of food conversion for milk production in British Friesian and Jersey cattle. British Cattle Breeders Club, Winter Conf. pp. 18-20.

Gilmour, A.R., Cullis, B.R., Welham, S.J. \& Thompson, R., 1999. ASREML - Reference Manual. NSW Agriculture Biometric Bull. No. 3. NSW Agriculture, Orange Agricultural Institute, Forest Road, Orange 2800, NSW, Australia.

Haile-Mariam, M., Morton, J.M. \& Goddard, M.E., 2003. Can milk protein percentage or yield serve as indicator of fertility (calving interval) in dairy cattle? Proc. Assoc. Advmnt Anim. Breed. Gen. 15, 7276.

Heinrichs, A.J. \& Hargrove, G.L., 1987. Standards of weight and height for Holstein heifers. J. Dairy Sci. 70, 653-660.

Kadarmideen, H.N. \& Wegmann, S., 2003. Genetic relationship among body condition score, type, fertility and production traits in Swiss Holstein cattle. Proc. Assoc. Advmnt Anim. Breed. Gen. 15, 77-81.

Koenen, E.P.C., 2002. Selection for body weight in dairy cattle in the Netherlands. Proc. $7^{\text {th }}$ World Cong. Appl. Livest. Prod. August, 19-23, 2002. Montpellier, France.

Koenen, E.P.C., Berentsen, P.B.A. \& Groen, A.F., 2000. Economic values of live weight and feed-intake capacity of dairy cattle under Dutch production circumstances. Livest. Prod. Sci. 66, 235-250.

Livestock Improvement Corporation, 1996. Animal Evaluation Technical Manual. New Zealand Dairy Industry. Animal Evaluation Unit, Private Bag 3016, Hamilton, New Zealand.

Lopez-Villalobos, N. \& Garrick, D.J., 2003. Accounting for feed intake in dairy cattle evaluation. Proc. Assoc. Advmnt Anim. Breed. Gen. 15, 318-321.

Madgwick, P.P., Beard, K.A. \& Goddard, M.E., 1991. Possibilities for incorporating selection for feed conversion efficiency into the national Dairy Herd Improvement Program. Proc. Assoc. Advmnt Anim. Breed. Gen. 15, 45-48.

Mostert, B.E., Theron, H.E. \& Kanfer, F.H.J., 2001. The effect of calving season and age at calving on production traits of South African dairy cattle. S. Afr. J. Anim. Sci. 31, 205-214.

Mostert, B.E., Theron, H.E. \& Kanfer, F.H.J., 2003. Derivation of standard lactation curves for South African dairy cows. S. Afr. J. Anim. Sci. 33, 70-77.

Muller, C.J.C. \& Botha, J.A., 2003. The response to selection during first lactation on the phenotypic and genetic trends in the Elsenburg Holstein-Friesland herd. S. Afr. J. Anim. Sci. 33, 111-116.

Mulvany, P., 1977. Dairy cow condition scoring. Nat. Inst. for Dairying, Shinfield, Reading RG2 9AT. Paper no. 4468.

NRC, 1989. Nutrient Requirements of Dairy Cattle. ( $6^{\text {th }}$ Rev. ed.). National Research Council, National Academy Press, Washington, D.C., USA.

Spelman, R.J. \& Garrick, D.J., 1997. Effect of live weight and differing economic values on responses to selection for milk fat, protein, volume, and live weight. J. Dairy Sci. 80, 2557-2562.

Vandehaar, M.J., 1998. Efficiency of nutrient use and relationship to profitability on dairy farms. J. Dairy Sci. 81, 272-282. 
Van Elzakker, P.J.M. \& Van Arendonk, J.A.M., 1993. Feed intake, body weight and milk production: genetic analysis of different measurements in lactating dairy heifers. Livest. Prod. Sci. 37, 31-51.

Veerkamp, R.F., 1996. Live weight and feed intake in dairy cattle breeding goal. Proc. Int. Workshop on Functional Traits in Cattle. Gembloux, Belgium, January, 21-23. Int. Bull Evaluation Services, Uppsala, Sweden.

Veerkamp, R.F., 1998. Selection for economic efficiency of dairy cattle using information on live weight and feed intake. A review. J. Dairy Sci. 81, 1109-1119.

Veerkamp, R.F. \& Brotherstone, S., 1997. Genetic correlations between linear type traits, food intake, live weight and body condition score in Holstein Friesian dairy cattle. Anim. Sci. 64, 385-392.

Verbyla, A.P., Cullis, B.R., Kenward, M.G. \& Welham, S.J., 1999. The analysis of designed experiments and longitudinal data using smoothing splines. J. Royal Stat. Soc., Series C 48, 269-311. 